\title{
Diversity and Distribution of Phytoplankton at selected sites of Jamnagar coast, Gujarat, India
}

\author{
Roshan Bhagat $^{1 *}$, Rajal Patel $^{2}$, Harshad Salvi ${ }^{3}$, Kamboj R.D. ${ }^{4}$ \\ ${ }^{1,2,4}$ Gujarat Ecological Education and Research Foundation, Gandhinagar, Gujarat, India \\ ${ }^{3}$ Department of Botany, Songadh Government Science College, Tapi, Gujarat, India \\ *Corresponding author: danish_0084@yahoo.co.in; Contact - +91-7573020442
}

Available online at: www.isroset.org

Received: 29/Sept/2019, Accepted: 15/Oct/2019, Online: 31/Oct/2019

\begin{abstract}
Phytoplanktons are the primary producer of marine ecosystems and contribute towards the primary productivity of aquatic environment. The present study was carried out at three selected sites of Gulf of Kachchh (GoK) viz; Pirotan, Sachana and Roziport. During the study, a total of 106 species of phytoplankton were recorded, of which the highest species diversity was found at Rozi followed by Pirotan and Sachana. The maximum number of species diversity was contributed by the class Bacillariophyceae with 81.5 percentage , 79 percentage and 83 percentage at Pirotan, Rozi and Sachana, respectively. Rozi port reported the highest number of harmful phytoplankton i.e. some members of Bacillariophyceae and Dinophyceae. The highest number of species was recorded at Rozi port (75 sp.) followed by Pirotan $(54 \mathrm{sp}$.) and Sachana (46 sp.). The varied environmental conditions prevailing at three study sites may cause variation in species composition at these sites.
\end{abstract}

Keywords- Coral reef, Island, Mangrove, Phytoplankton, Port, Sewage, ship breaking yard

\section{INTRODUCTION}

Phytoplanktons are group of photosynthetic microalgae that serve as a primary producer \& important component in the food web. They use solar radiation and $\mathrm{CO} 2$, nutrients and trace element to process their food. Phytoplankton imparts $20-25 \%$ of the world's total net primary production [1]. They initiate the marine food chain, by serving as food to primary consumers. Therefore, phytoplanktons are of great significance. Taxonomically, phytoplanktons taxonomic composition globally includes about 4000-5000 species [2 , 3] Life cycle of phytoplankton is mainly affected by abiotic factors such as salinity, light, temperature, turbulence, water quality \& other parameter. Phytoplanktons species are indicators of environmental changes, and long-term time-series are effective tools to evaluate and understand these changes [4].

\section{MATERIALS AND METHODS}

\section{Study area:}

Gulf of Kachchh (GoK) is an extension of Arabian Sea \& located in $22^{\circ} 15^{\prime} \mathrm{N}$ to $23^{\circ} 40^{\prime} \mathrm{N}$ latitude and $68^{\circ} 20^{\prime}$ to $70^{\circ} 40^{\prime} \mathrm{E}$ longitude. It has an area of 7350 sq.km and depth varies from less than 10 meters at head and 60 meters at outer region [5]. The average depth in Gulf of Kachchh is of 30 meters. It has higher evaporation rate as compared to precipitation rate [6] and receives inflow of water only in monsoon. Some portions of the coastal area from Okha to Jodiya have been declared as Marine National park \& Sanctuary. These areas are rich in wide range of habitats, including Coral reef, Mangroves, Mudflats, saltpans that support biodiversity of plants and animals. The area also supports livelihood of local people. It has fish landing centers, fisheries processing units, many small and medium ports, wood processing industry, salt pans, Brine industry, and Special Economic Zones. 


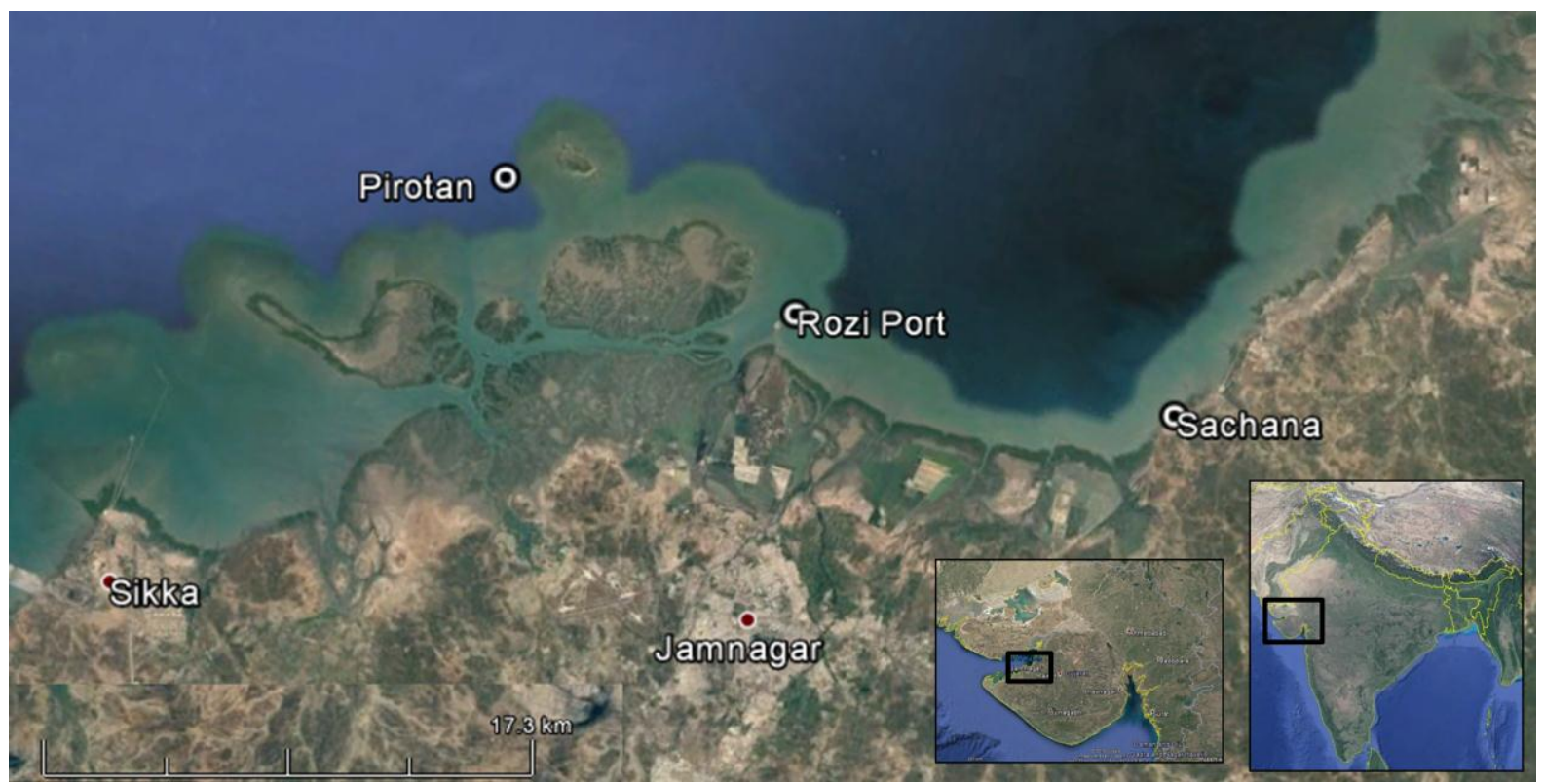

Fig: 1 Map showing study area of the map and selected sites of Gulf of Kachchh (Google images)

Site description: The present study was carried out at three sites of GoK viz; Pirotan island, Sachana \& Rozi port. The site location and GPS points of the same are shown in Figure 1 and Table 1 respectively.

Table: 1 Description of selected sites for sample Collection.

\begin{tabular}{|l|l|l|l|l|}
\hline SN. & Site & Latitude (N) & Longitude ( E) & Description \\
\hline 1 & Pirotan (PI) & $22^{\circ} 35^{\prime} 13.3^{\prime \prime}$ & $69^{\circ} 56^{\prime} 21.6^{\prime \prime}$ & Mangrove and Coral reef \\
\hline 2 & Sachana (SA) & $22^{\circ} 34^{\prime} 18.83^{\prime \prime}$ & $70^{\circ} 10^{\prime} 55.24^{\prime \prime}$ & Ship breaking yard \\
\hline 3. & Rozi (RO) & $20^{\circ} 43^{\prime} 16.99^{\prime \prime}$ & $70^{\circ} 2^{\prime} 42.31^{\prime \prime}$ & Port \\
\hline
\end{tabular}

Pirotan: Pirotan is an island located in Gulf of Kachchh. It comes under Marine National Park, Jamnagar, Gujarat state, India. It is located at a distance of 12 nautical miles from Bedi port. It comprises of mangroves, coral reefs and low-tide beaches, and has an area of 3 square kilometers. Pirotan has rich marine biodiversity [7].

Sachana: Sachana is situated $25 \mathrm{~km}$ away from Jamnagar. The village has important fish landing center. Sachana coastal area used to have ship breaking yard. At the time of ship wreck, engine oil, other garbage and non biodegradables material released from the ships used to spread in other area. Coastal area from Khijadiya to Sachana is rich in mangrove.

Rozi port: Rozi port is an intermediate port\& falls under Marine sanctuary. The ships are loaded and unloaded at Roziport. That may increase the chance of spreading of pollutants. Inflow of Nagmati and Rangmati rivers brings the flow of sewage of Jamnagar city at this site. Therefore, the site was chosen for investigation.

Methodology: The phytoplankton samples were collected during the year 2011 to 2014 on monthly basis. The samples were collected by grab sampling. During sampling, five liters of water sample was collected in bucket and this water was passed through $20 \mu$ mesh size sieve. The samples were collected in $250 \mathrm{ml}$ plastic bottle and preserved in $1 \mathrm{ml} 4 \%$ formaldehyde solution. For microscopic observation, $0.1 \mathrm{ml}$ of preserved sample was taken and analyzed by Lackey's drop method. The samples were observed under light microscope (made Gippon). The phytoplanktons were identified using the book on Identifying Marine phytoplankton [8].

\section{RESULTS AND DISCUSSION}

A total of 106 species have been reported from study area. Fig. 2 illustrates the number of families, genera, and species recorded at studied sites. The checklist of phytoplankton species is mentioned in Table 2. The highest number of species was recorded from Rozi port followed by Pirotan and Sachana. 


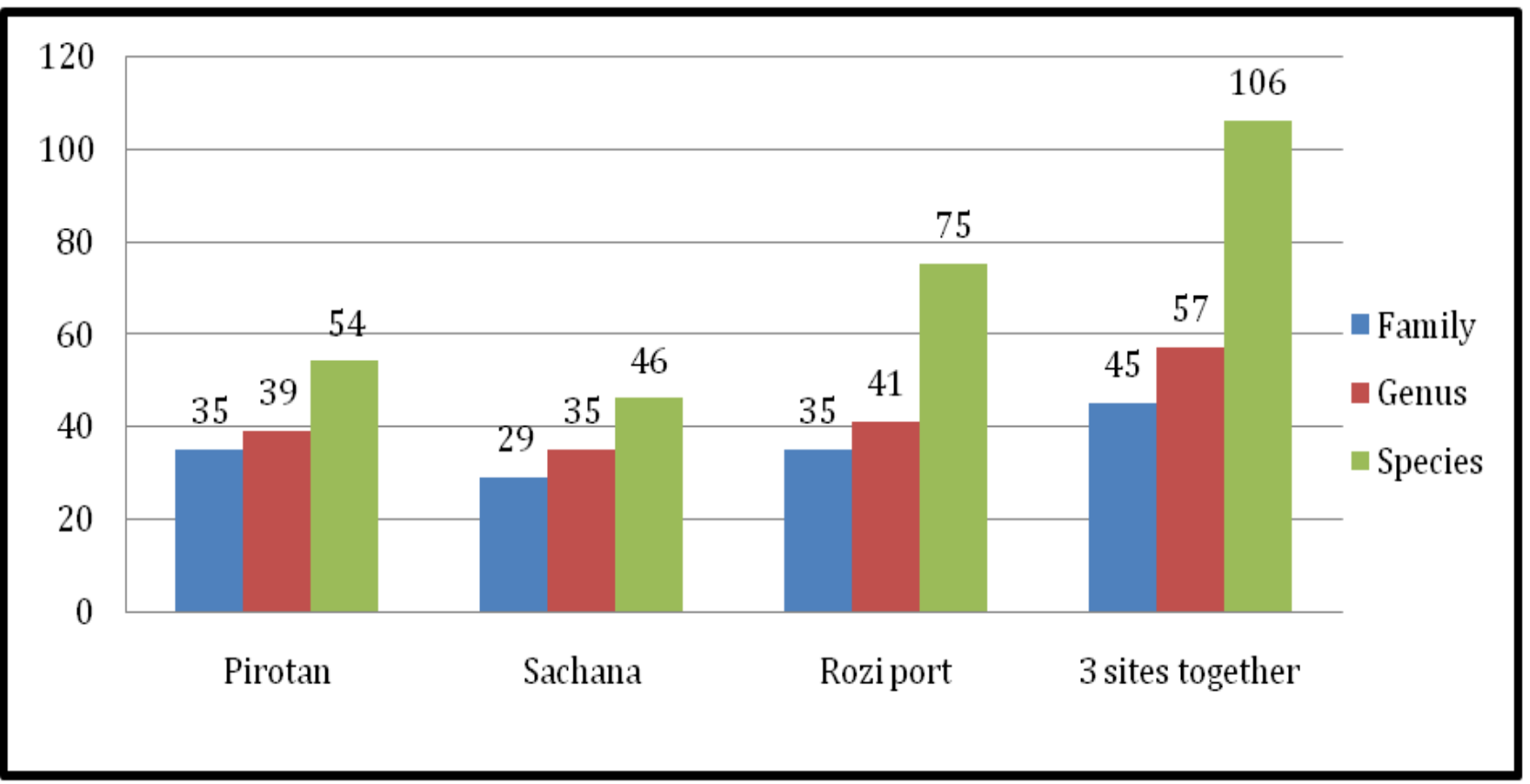

Fig : 2 Site wise number of family, Genus and Species.

The contribution of different classes to phytoplankton population at three sites is depicted in Fig. 3. The study has recorded presence of 8 classes viz; Bacillariophyceae, Chlorophyceae, Cyanophyceae, Dinophyceae, Conjugatophyceae, Trebouxiophyceae, Ulvophyceae, and Xanthophyceae. The class Bacillariophyceae had highest \% distribution at all sites followed by Dinophyceae. Similar kinds of results were obtained for Orissa coast [9]. Several other researchers also found dominance of Bacillariophyceae (i.e. Diatoms) followed by Dinoflagellates [4, 10, 11]. There was variation in distribution of species at three sites From the present study it was observed that, 24 species of phytoplanktons were common at all the sites which includes Achnanthidium minutissimum, Ceratiumgibberum sp., Ceratiumlineatum sp., Chaetocerosdecipiens sp.," Coscinodiscusrobustus sp., Diploneis crabro, Eucampiazodiacus sp., Fragilaria capucina , Gyrosigma acuminatum. Minidiscus trioculatus, Navicula lanceolata, Nitzschia palea, Nitzschia radicula, Nitzschia tryblionella, Odontella mobiliensis, Pediastrum boryanum, Picochlorumatomus sp.,, Pinnularia microstauron, Pinnularia sp., Protoperidinium divergens, Scenedesmus pulloideus, Taberllaria fenestrata, Thalassionema nitzschioides, and Thallassiosira punctigera.

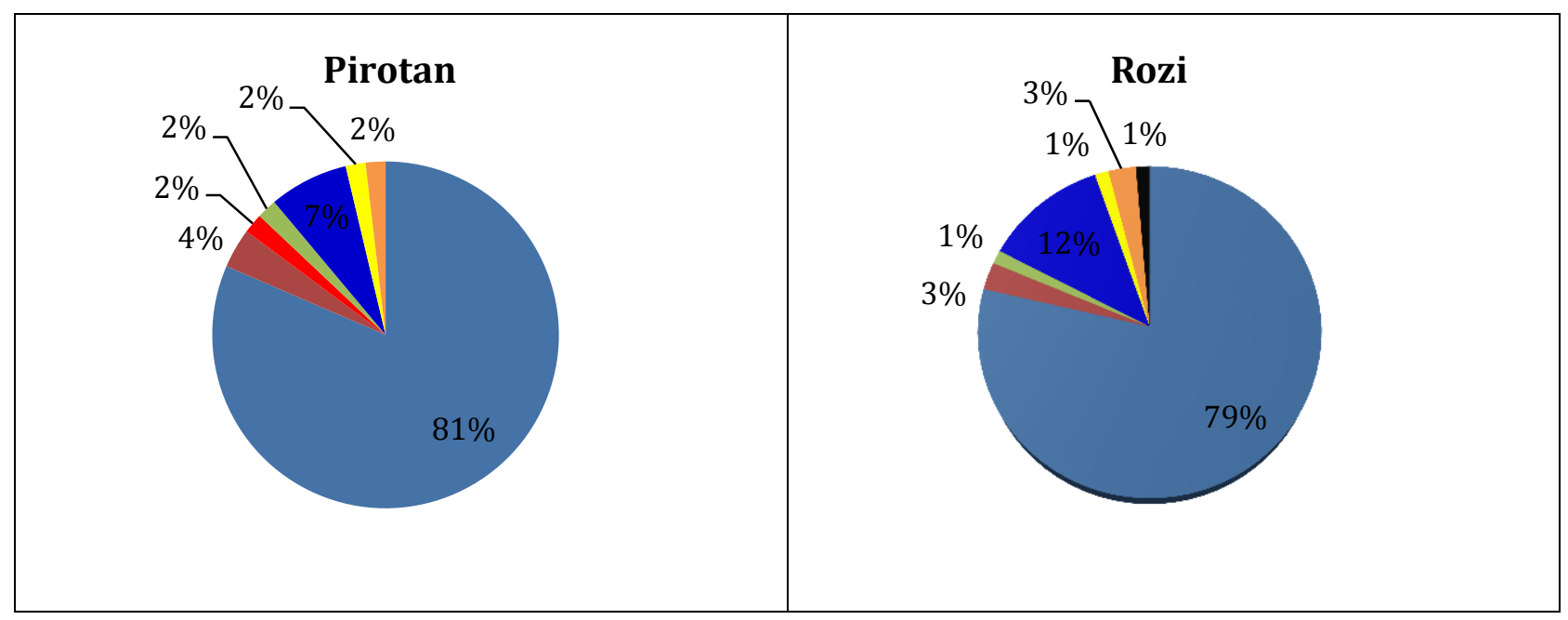




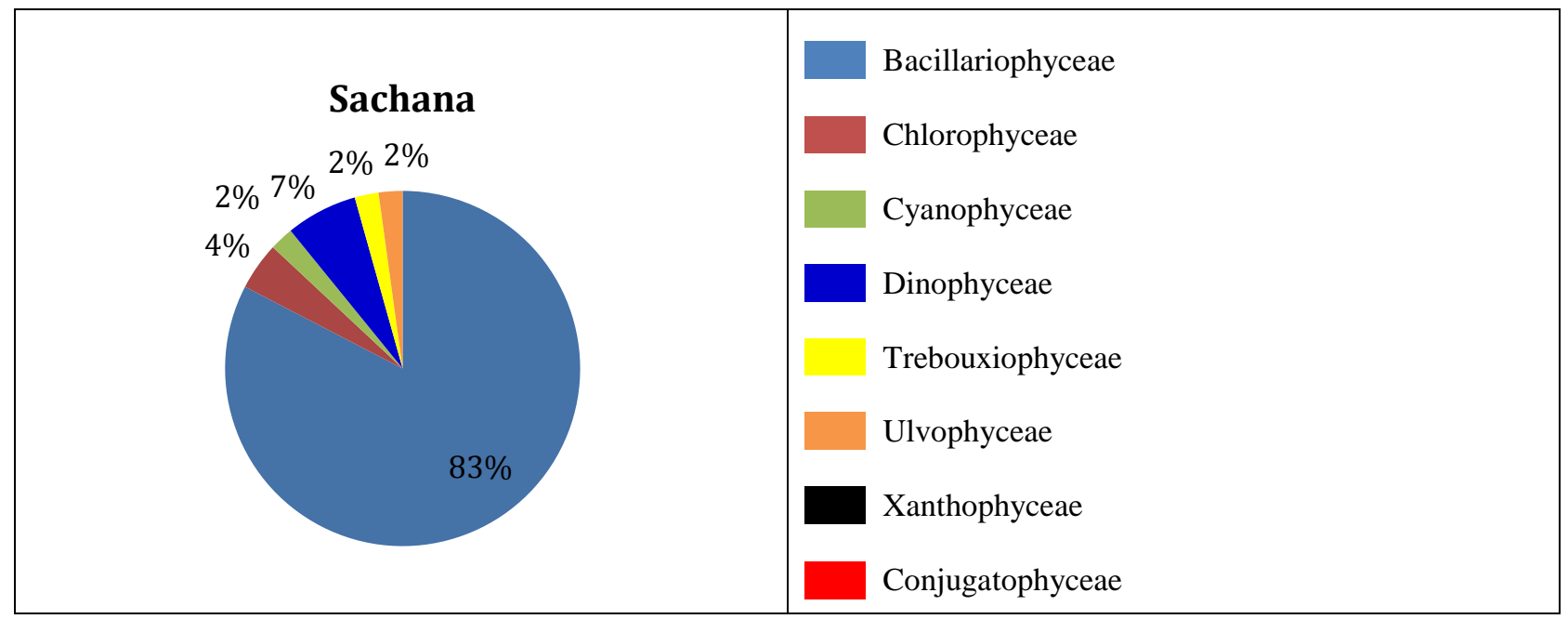

Fig: 3 Class wise percentage contribution of phytoplankton at three selected sites.

The overall class-wise distribution of species at three sites showed highest percentage of Bacillariophyceae (81.5\%) followed by Dinophyceae (4\%), Chlorophyceae (3.7\%), Conjugatophyceae (1.9\%), Cyanophyceae, Trebouxiophyceae (1.9\%), and Ulvophyceae (1.9\%).

Pirotan: The site Pirotan showed dominance of two genera, namely, Nitzschia sp. and Rhizosolenia representing seven and three species of phytoplanktons, respectively. The class xanthophyceae was absent from Pirotan. There are about seventeen species that are exclusively present at this site; these species may be sensitive to change in abiotic and biotic factors and include Actinocyclus octonarius, Asteromphalus sp., Cocconeis oblonga, Gomphonema gracile, Manguinea regida, Nitzschia recta, Nitzschia linearis, Pleurosigma falcatum, Protoperidinium pellucidum, Rhizoclonium tortuosum, Rhizosolenia acicularis, Rhizosolenia robusta, Spirogyra hyalina, Surirella caproni, Surirella patella, Synedra ulna ,and Thalassiosira oestrupii.

Rozi: It is located on Jamnagarcoast of the GoK. The Rangmati and Nagmati rivers discharge sewage and industrial effluents in this area. Similar to other two sites, this site also showed highest \% distribution of Bacillariophyceae (79\%) followed by Dinophyceae (12\%), Chlorophyceae (3\%), Cyanophyceae(1\%), Trebouxiophyceae (1\%), Ulvophyceae (3\%), Xanthophyceae $(1 \%)$. The genus Nitzschia was found to be dominant (9 species) followed by Pleurosigmaand Pseudo - nitzschia (4 species each), whereas Odontella Prorocentrum and Thalassiosira were represented by three species of each genus. Other species are mentioned in checklist (Table 2). Among three selected sites, the highest number of Dinophyceae (12\%) species was reported from this site. Moreover, the site showed presence of certain species of diatoms i.e. Pseudo-nitzschia seriata, Pseudo-nitzschia turgidula and Pseudo-nitzschiamultiseries and some genera of dianoflagellates namely Gymnodinium sp., Protoperidinium sp. and Prorocentrum sp. which are known to be toxic in nature and may negatively impact the organisms present in that ecosystem.

Sachana: This site is mainly used as fish landing centre. This study reported occurrence of $83 \%$ of Bacillariophyceae followed by Dinophyceae $(7 \%)$ and Chlorophyceae $(4 \%)$, whereas the Cyanophyceae, Trebouxiophyceaeand Ulvophyceae each contributed 2\% respectively to the total population of Phytoplankton at this site. This site showed presence of four species of Nitzschia and three species of Coscinodiscus. Other species of phytoplankton are mentioned in Table2.There are five species of phytoplankton namely Corethron pennatum, Nitzschia acicularis,Pseudo-nitzschia multiseries, Rhizoclonium sp., Rhizosolenia imbricata which were recorded from Rozi and Sachana only. Both these sites receive pollutant by anthropogenic means. Therefore, these species may be treated as pollution tolerant species.

Overall, there are 24 species that are common at the three studied sites which might be due to the ability of these phytoplankton to acclimatize all types of environment [12]. The study also revealed presence of certain species that forms "Harmful Algal Blooms (HABs)".Additionally, five species of Pseudo-nitzschia were observed from Sachana and Rozi which are known to produce and release toxin (Domoic acid) [13]. Some diatoms belonging to genus Chaetoceros are responsible for damaging fish gills and cause inflammatory responses, making them susceptible to infection. Again certain species of Dinoflagellates and Rhizosolenia imbricate causes red tide [14] which is also reported in the present study. 


\section{CONCLUSION}

The present study revealed diversity and distribution of phytoplankton variation among three sites of southern GoK. The variation in species distribution may be due to environmental conditions prevailing there. Harmful diatom species belonging to genus Pseudo-nitzschia were not encountered from Pirotan. Moreover, only three species of Dinophyceae were found to be present at this site; hence this site can be considered as non-polluted. On the other hand, Rozi has the highest number of harmful phytoplankton species and therefore, regular monitoring of water samples is required in this area.

Plate: 1 Glimpse of Phytoplankton observed from three sites of Jamnagar coast, GoK.

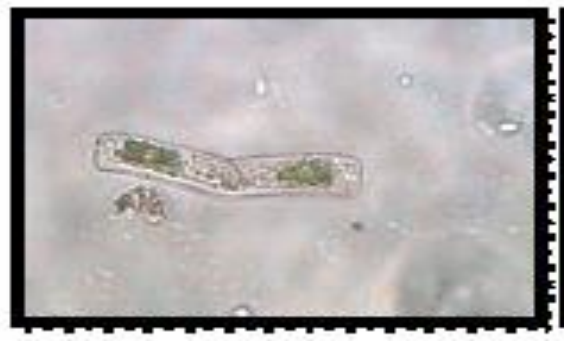

Achnanthes minutissimum

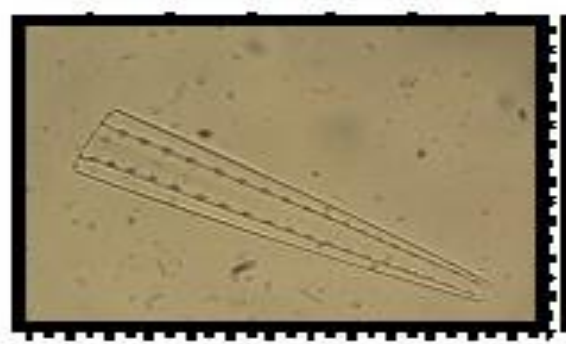

Climacosphenia moniligera

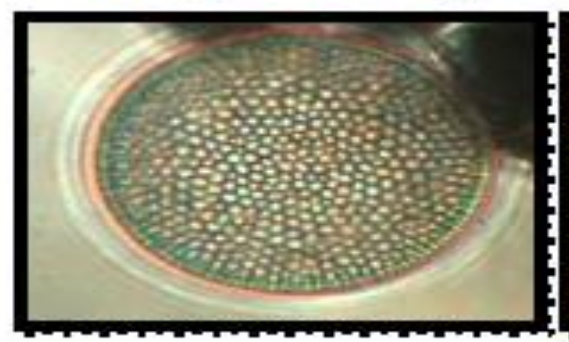

Coscinodiscus centralis

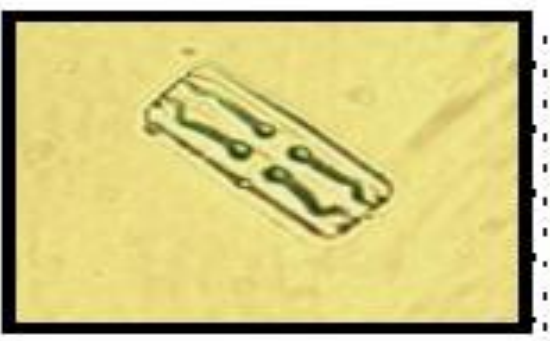

Grammatophora undulata

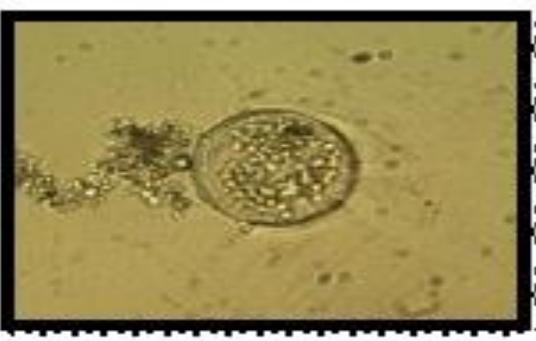

Actinoptychus senarius

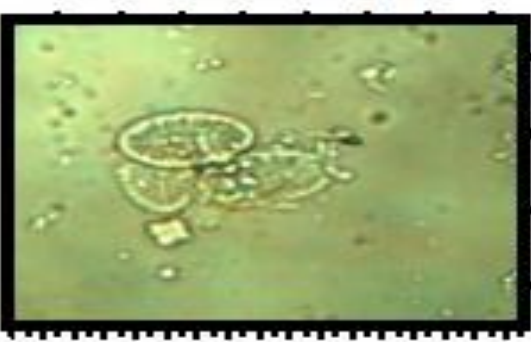

Cocconeis placentula

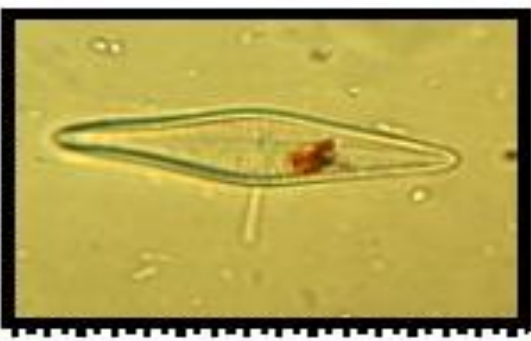

Gomphonem a gracile

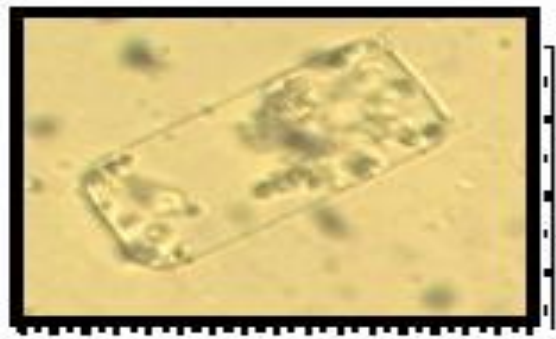

Guinardia delicatula

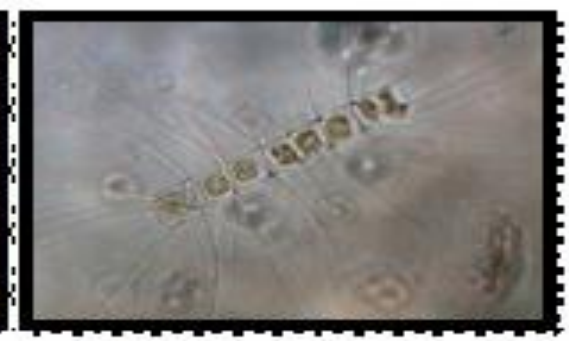

Chaetoceros decipiens

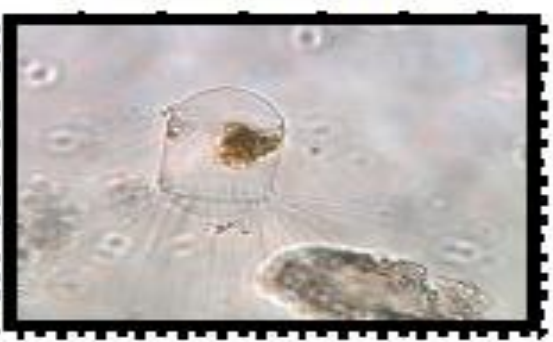

Corethron criophilum

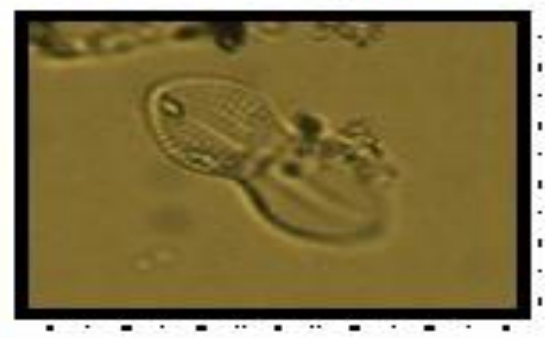

Diploneis crabro

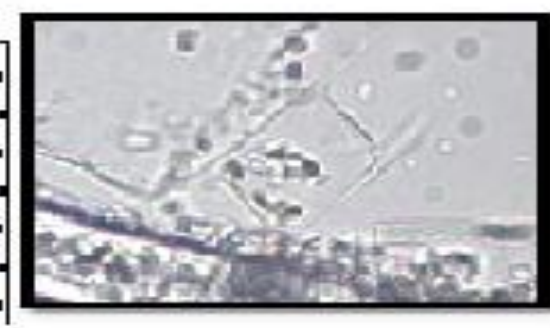

Hemiaulus membranaceus 
Plate: 2 Glimpse of Phytoplankton observed from three sites of Jamnagar coast, GoK.
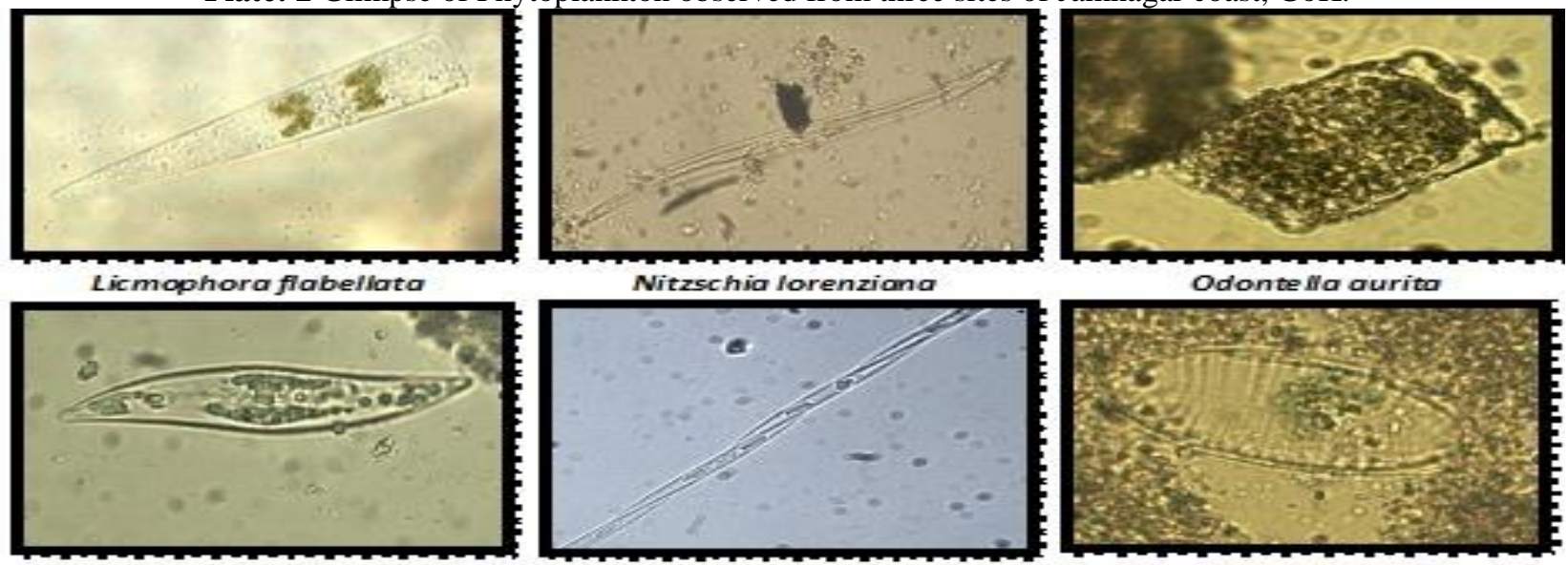

Nitzschia forenziana

Odonte fla aurito
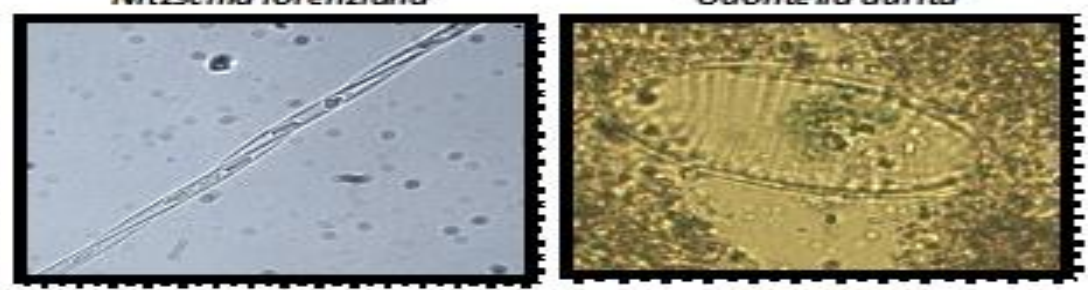

Pleurosigma angulatum

Pseudo nitzschia multiseriata
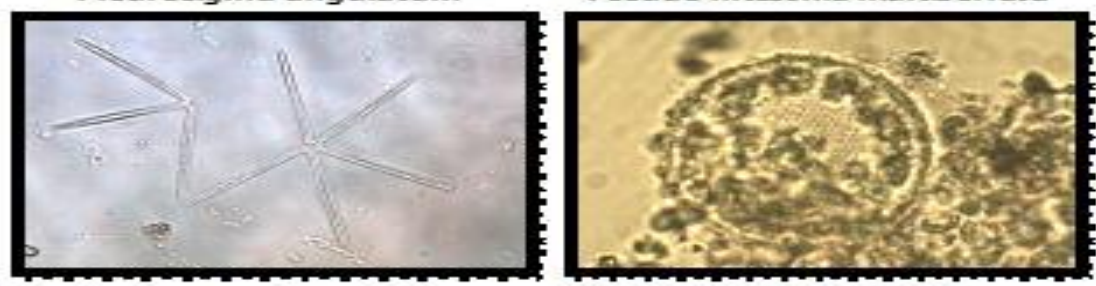

Surire Ifa $s p$.

Thalassionema nitzschioides

Thallassiosira punctigera
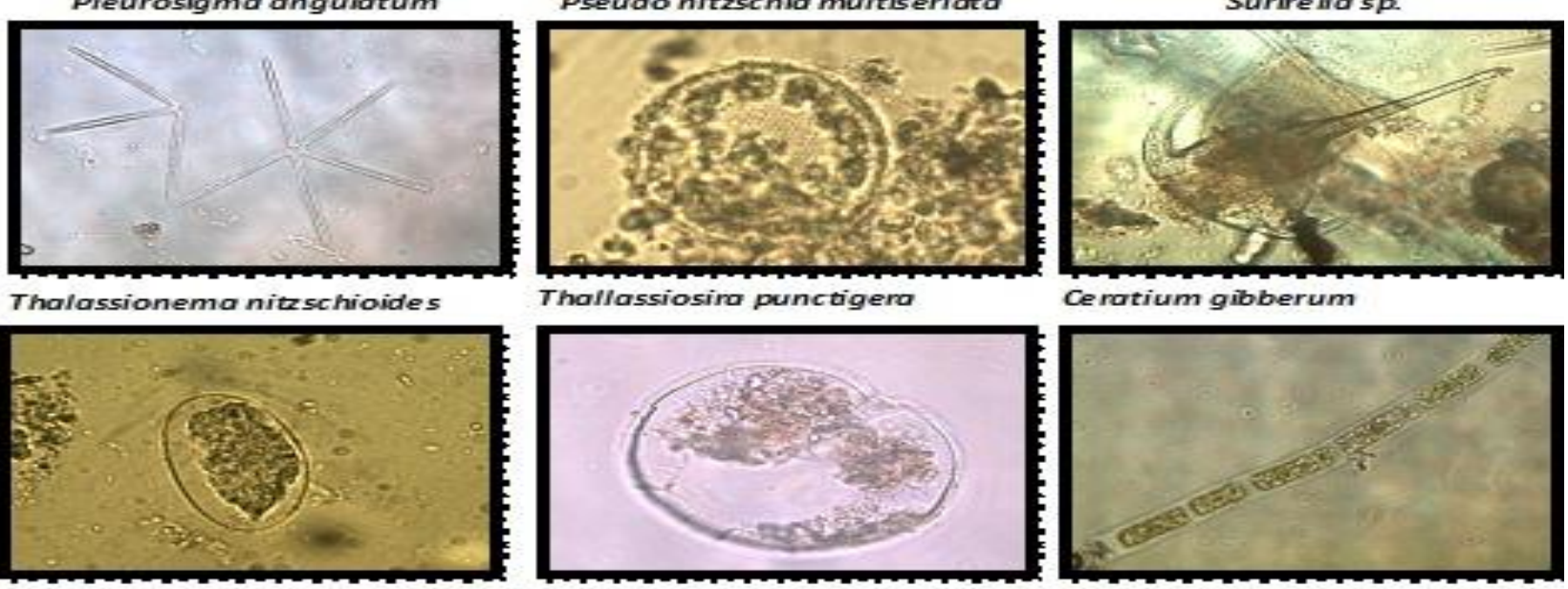

Ceratium gibberum

Promacentrum compresum

Nactiluca scintilfans

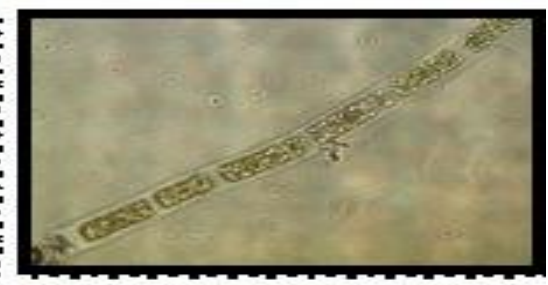

Rhizoclonium sp.

\section{ACKNOWLEDGEMENTS}

Authors are thankful to World Bank; Department Of Forest \& Environment, Government of Gujarat; Gujarat Ecology Commission- State Project Monitoring Unit (GEC-SPMU), for providing fund under Integrated Coastal Zone Management Project for this research activity. Authors would like to thank Department of Forests- Government of Gujarat and Marine National Park \& Sanctuary for providing the permission to carry out this research. Authors are also thankful to officers of Gujarat Pollution Control Board for their co - operation in research activity. The Director and Scientist of BSI are highly acknowledged for their support in authenticating the identified phytoplankton species. Authors are also thankful to Director GEER Foundation, Gandhinagar, for providing guidance and opportunity to publish this work. The support of other research staff of GEER Foundation for field data and sample collection is duly acknowledged.

\section{REFRENCES}

[1]. Werner, D., "Contribution of the study of diatoms to biology." In Werner D. (ed) The biology of diatom: Blackwell, Oxferd, (P-1-3), 1977.

[2]. Sournia, A., J. Chrétiennot-Dinet and M. Ricard, "Marine plankton: how many species in the world oceans?", Journal of Plankton Research, 13: 1093 $-9,1991$.

[3]. Tett,P.and E.D.Barton, "Why are there about 5000 species of phytoplankton in the sea ?", Journal of Plankton Research Vol.17 no.8 pp. $1693-$ $1704,1995$.

[4]. Hays, G.C. \& A.J. Richardson, and C. Robinson, "Climate change and marine plankton. Trends in ecology \& evolution”, Vol. 20 (6) 337 - $44,2005$.

[5]. Vethamony P. and M.T. Babu, "Physical process in Gulf of Kachchh: A Review Indian”, J. Geo-Mar. Sci. 39(4), 497-503, 2010.

[6]. Sen Gupta, R. and G. Deshmukhe, "Coastal and maritime environments of Gujarat: Ecology and Economics.”, Gujarat Ecological Society, pp. 150, 2000 . 
[7]. Singh H. S., C.N. Pandey, P. Yennawar, R.J. Asari, B.H. Patel, K. Tatu, and B.R. Raval, “ The marine national park and sanctuary in the Gulf of Kachchh-a comprehensive study on biodiversity and management issues." GEER Foundation, Gandhinagar, 2004.

[8]. Tomas, C.R. (Ed.), "Identifying marine phytoplankton. Academic press", 1997.

[9]. Panda S.S., N.K.Dhal, and C.R. Panda, "Phytoplankton diversity in response to abiotic factors along Orissa coast, Bay of Bengal", Int J Environ Sci, 2, 3-8, 2012 .

[10]. Rajasekar K. Thillai, M. Rajkumar, Jun Sun, Prabu V. Ashok, P. Perumal, "Seasonal variations of phytoplankton diversity in the Coleroon coastal waters, southeast coast of India",Acta Oceanol. Sin., , Vol. 29, No. 5, P. 97-108, 2010.

[11]. Dayala, V.T., P.M. Salas, C.H. Sujatha, "Spatial and seasonal variations of phytoplankton species and their relationship to physicochemical variables in the Cochin estuarine waters, Southwest Coast of India" Indian Journal of Geo-Marine Sciences, Vol. 43 (6), pp. 937-947, 2013.

[12]. Subrahmanyan, R. and A.H. Viswanatha Sarma, "Studies on the phytoplankton of the west coast of India. Part III. Seasonal variation of the phytoplankters and environmental factors.", Indian J. Fish., 7 (2): 307-336, 1960.

[13]. Fehling,J., K. Davidson, C.J. Bolch, and S.S. Bates, "Growth and domoic acid production by Pseudo-nitzschiaseriata (Bacillariophyceae) under phosphate and silicate limitation." Journal of Phycology, 40 (4), 674-683, 2004.

[14]. Tsutsumi, H., "Critical events in the Ariake Bay ecosystem: clam population collapse, red tides, and hypoxic bottom water", Plankton and Benthos Research, 1(1), 3-25.

[15]. Al-Kandari, M., F.Al-Yamani,and K. Al-Rifaie, "Marine phytoplankton atlas of Kuwait's waters. Kuwait Institute for Scientific Research (Publisher)," 2009.

[16]. Kedong, Yin Monsoonal, "Influence on seasonal variations in nutrients and phytoplankton biomass in coastal waters of Hong Kong in the vicinity of the Pearl River estuary.” Mar EcolProgSer 245: 111-122 2002.

[17]. Panda S.S., N.K.Dhal, andC.R. Panda, "Phytoplankton diversity in response to abiotic factors along Orissa coast, Bay of Bengal. Int J Environ Sci, 2, 3-8 2012.

[18]. Pandiyarajan, R.S., P.S.Shenai-Tirodkar, M. AyajuddinandZ.A. Ansari, "Distribution, abundance and diversity of Phytoplankton in the inshore waters of Nizampatnam, South East coast of India", India Journal of Geo -Marine Science, Vol. 43 (3), pp. 348 - 356 March 2014.

[19]. Shruthi M.S., and M. Rajashekhar, "Ecological observations on the phytoplankton of Netravathi-Gurupura estuary, South west coast of India." J. Mar. Biol. Ass. India, 55, 1-7, 2014.

\section{Author Profile}

Mr. Roshan Bhagat, is junior research fellows working on Water, waste water, Soil and Plankton (Environment) study in Gujarat Ecological Education and Research (GEER) Foundation, Gandhinagar. He has completed his Master of Science in the field of Environment Science from the Bharati Vidyapeeth Institute of Environment Education and Research University, Pune, Maharashtra. He has been actively involved in Environmental study of Coastal area and wetland of Gujarat for last 8 years. He has also been contributing in various ecological awareness activities at GEER Foundation.

Dr. Rajal Patel, has completed her Ph.D. in Environmental Science from Sardar Patel University and is a Research Associate at GEER Foundation, Gandhinagar. She has been working on Coastal \& Marine Environment and published six research papers.

Dr. Harshad Salvi, has done his Ph.D. from HNGU, Patan, was actively involved in a number of biodiversity of Protected Areas (Pas) at Gujarat State related to plant diversity as well as pollination biology $\&$ reproductive ecology of rare mangrove species studies as scientist in GEER Foundation. He has over 18 years of research experience in coastal, corals, grassland and forest ecosystems of Gujarat State and has published 12 research Papers. Presently he is serving as Assistant professor and Head, Botany Department, Government Science College, Songadh, Tapi, Gujarat.

Mr. R. D. Kamboj, is an Indian Forest Services Officer of Gujarat cadre (1986 batch) of the rank of Additional Principal Chief Conservator of Forests. He holds post graduate degree in Agriculture from Haryana Agriculture University, Hisar \& in Forestry from Indira Gandhi National Forest Academy, Dehradun. He has served in various positions in Gujarat Forest Department for last 32 years. He has published more than 70 research papers and has written Working Plans/ Management Plans for various forest divisions including Gir National Park \& Sanctuary. Presently he is serving as Director, Gujarat Ecological Education and Research (GEER) Foundation, Gandhinagar.
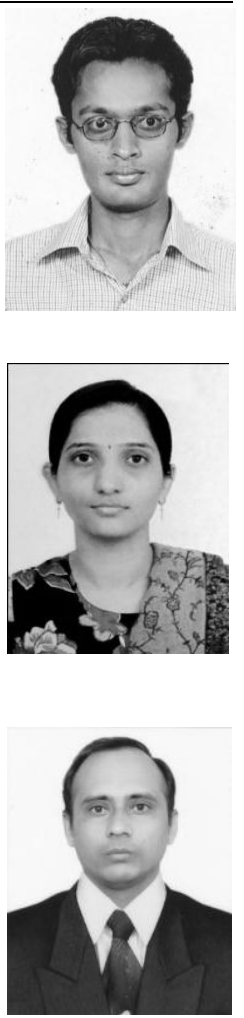